\title{
Application of bio-silicic acid to improve yield and fertilizer efficiency of paddy on tidal swamp land
}

\author{
Aplikasi bio-asam silika untuk meningkatkan produksi dan efisiensi pemupukan padi pada lahan rawa \\ pasang surut \\ Donny N. KALBUADI ${ }^{1 *}$ ), Laksmita P. SANTI ${ }^{1)}$, Didiek H. GOENADI ${ }^{1)}$, \& Yunita BARUS ${ }^{2)}$ \\ 1) Indonesian Research Institute for Biotechnology and Bioindustry, Jl. Taman Kencana No.1, Bogor 16128 \\ 2) Assessment Institute of Agricultural Technology \\ Jl. Zainal Abidin Pagar Alam No. 1A, Rajabasa, Bandar Lampung 35145
}

Diterima tgl 19 Mei 2020/ disetujui tgl 5 Oktober 2020

\begin{abstract}
Abstrak
Tanah di lahan rawa pasang surut sebagai daerah pengembangan baru untuk padi di Indonesia memiliki silika (Si) tersedia yang cukup rendah karena kondisi asam dan tidak ada pemupukan Si. Oleh karena itu, untuk meningkatkan produktivitas padi sebagai tanaman akumulator Si, di lahan rawa pasang surut membutuhkan pemupukan silika. Penelitian ini menyajikan pengaruh aplikasi silika dalam bentuk asam silika $\left(\mathrm{H}_{4} \mathrm{SiO}_{4}\right)$ yang diperkaya dengan fungi pelarut silika (BioSilAc), dan diformulasikan dalam bentuk pupuk Si tablet 4-gram, di tanah lahan rawa pasang surut untuk meningkatkan hasil dan mengurangi dosis pupuk kimia pada padi. Percobaan lapangan dilakukan di Kecamatan Ketapang, Lampung Selatan menggunakan rancangan acak kelompok ( $R A K)$ dengan enam perlakuan dan empat ulangan, dengan masingmasing ukuran petak seluas $200 \mathrm{~m}^{2}$. Perlakuan terdiri dari (ha musim $^{-1}$ ): 100\% NPK dosis rekomendasi (P1); $100 \%$ NPK +80 tablet BioSilAc (P2); $75 \%$ NPK +80 tablet BioSilAc (P3); 75\% NPK +100 tablet BioSilAc (P4); 50\% $N P K+120$ tablet BioSilAc (P5); dan kontrol (P6). Hasil penelitian menunjukkan bahwa perlakuan P2 meningkatkan hasil berupa gabah kering panen tertinggi sebesar 7,6\% atau setara dengan $500 \mathrm{~kg}$ $\mathrm{ha}^{-1}$ dibandingkan dengan perlakuan Pl. Efisiensi pemupukan tertinggi dicapai pada perlakuan P4 yang berarti dosis pupuk NPK rekomendasi dapat dikurangi 25\% dengan menambahkan 100 tablet BioSilAc ha ${ }^{-1}$ musim $^{-1}$ yang ditunjukkan oleh produktivitas yang tidak berbeda secara signifikan dengan perlakuan P1. Nilai Revenue/Cost $(R / C)$ menunjukkan perlakuan P2 layak secara ekonomi untuk pemupukan tanaman padi.
\end{abstract}

[Kata kunci: pupuk silika, fungi pelarut silika, silika larut air]

*) Corresponding author: donny.nugroho33@gmail.com

\begin{abstract}
The soils in tidal swamp land as new development area for rice in Indonesia have a considerably low available silica ( $\mathrm{Si}$ ) because very acid condition and no Si fertilization. Therefore, increasing the productivity of rice as $\mathrm{Si}$ accumulator plant, in tidal swamp land requires silica fertilizer. This research presented the effect of applications of silicon in the form of orthosilicic acid $\left(\mathrm{H}_{4} \mathrm{SiO}_{4}\right)$ enriched with selected $\mathrm{Si}$ solubilizing fungi, formulated as 4-gram tableted Si fertilizer (BioSilAc) on tidal swamp land soil to improve yield and reduce chemical fertilizer dosage for rice. Field experiment was conducted in Ketapang subdistrict, South Lampung by using a Randomized Block Design (RBD) with six treatments and four replicates. The treatments consisted of $\left(\mathrm{ha}^{-1}\right.$ season $\left.^{-1}\right): 100 \%$ NPK recommended dosage $(\mathrm{P} 1) ; 100 \% \mathrm{NPK}+80$ BioSilAc tablets (P2); 75\% NPK +80 BioSilAc tablets (P3); 75\% NPK +100 BioSilAc tablets (P4); 50\% NPK + 120 BioSilAc tablets (P5); and control (P6). The results showed that P2 treatment increased the highest rice yield in dried harvested grain by $7.6 \%$ or equivalent to $500 \mathrm{~kg} \mathrm{ha}^{-1}$ compared to $\mathrm{P} 1$ treatment. The highest fertilization efficiency can be achieved in P4 treatment which means the NPK recommended dosage can be reduced $25 \%$ by adding 100 BioSilAc tablets ha ${ }^{-1}$ season $^{-1}$ indicated by insignificantly different productivity compared to that of P1. The Revenue/Cost (R/C) values showed that P2 treatment was economically feasible fertilization practices.
\end{abstract}

[Keywords: Si fertilizer, Si-solubilizing fungi, water-soluble $\mathrm{Si}]$

\section{Introduction}

Rice is known as silica ( $\mathrm{Si}$ ) accumulator plant (Alvarez \& Datnoff, 2001). The potential of Si in improving crop yield has been presented by many researchers, especially under abiotic and biotic 
stresses (Keeping \& Reynold, 2009; Meena et al., 2014; Farooq \& Dietz, 2015). Moreover, Si has been shown as a key nutrient to improve and stabilize rice yield (Ma \& Takahashi, 2002; Ahmad et al., 2013; Rao et al., 2017), and to control soilborne pathogen (Botta et al., 2014) and leaf blast (Fillipi et al., 2014). Goenadi et al. (2018) also found that application of $\mathrm{Si}$ on wetland rice improved yield and reduced NPK fertilizer dosage. These evidences taken place almost all over the world indicating the important role of $\mathrm{Si}$ as a functional nutrient for crops.

The development of tidal swamp land is to be considered as one of the efforts in responding to the challenges for increasing agricultural production in a sustainable way, which becomes increasingly complex. Sustainable land management in tidal swamp area is an important effort to get optimum and economic returns. Tidal swamp land has good prospects to be developed into productive agricultural land with proper management through the application of appropriate technological innovations. The main limiting factors for the development of tidal swamp land are low soil fertility; acid soil reactions; the presence of pyrite $(\mathrm{FeS})$; high levels of $\mathrm{Al}, \mathrm{Fe}, \mathrm{Mn}$, and organic acids; P deficiency; and poor bases content of $\mathrm{Ca}, \mathrm{K}$ and $\mathrm{Mg}$; as well as inhibition microbial activity (Lestari et al., 2019; Arsyad et al., 2014). In tidal swamp land, the soils have a low available Si due to a very low soil $\mathrm{pH}$ and the fact that $\mathrm{Si}$ fertilization is not a common practice yet (Siregar \& Yusuf, 2020). These conditions will consequently result in the depletion of soil Si over prolong time which leads to the decreasing crop yield, especially for rice as a $\mathrm{Si}$ accumulator crop. Therefore, Si fertilization is necessary to resolve the problem particularly with a fertilizer technology which adapts to tidal swamp land characteristics.

Many Si fertilizer products have started to be available in the market during the last few years with various quality as most of them are somewhat misleadingly based on total $\mathrm{SiO}_{2}$ content as quality indicator which actually unavailable to plants instead of soluble $\mathrm{Si}$. It has been reported that plants absorb $\mathrm{Si}$ in the form of silicic acid $\left(\mathrm{H}_{4} \mathrm{SiO}_{4}\right)$ only (Botta et al., 2014; Sahebi et al., 2015). Currently, there is a new Si fertilizer formulated by the Indonesian Research Institute for Biotechnology and Bioindustry (IRIBB), i.e. bio silicic acid so-called BioSilAc, which combines the microbial and nanotechnological approaches (Santi \& Goenadi, 2017). The formula has been shown improving performances of oil palm, sugarcane, and soybean against drought stress (Goenadi et al., 2019; Amanah et al., 2019; Santi et al., 2019; Santi et al., 2018). However, the impact of using BioSilAc to rice grown on soils in tidal swamp area has not been reported yet. Therefore, this research was aimed to evaluate the effect of BioSilAc application to improve yield and fertilizer efficiency of paddy on tidal swamp land.

\section{Material and Methods}

\section{Location and design of experiment}

This research was carried out in tidal swamp land, Ketapang Subdistrict, South Lampung starting from August to October 2019 (dry season) on a highly weathered soil belong to Kanhapludults subgroups (Wiryawan et al., 2001). Chemical characteristics of the tidal swamp land for the experimental plot were as follow: $\mathrm{pH} 4.4$, C-organic $2.05 \%$, total-N $0.221 \%$, total-P $0.023 \%$, total-K $0.033 \%$, CEC $20.99 \mathrm{cmol} \mathrm{kg}^{-1}$, and available $\mathrm{Si}\left(\mathrm{H}_{2} \mathrm{SiO}_{4}\right) 21.0 \mathrm{ppm}$. A randomized block design (RBD) was used to examine six fertilization treatments with four replicates and each plot size of $200 \mathrm{~m}^{2}$. The treatment consisted of $\left(\mathrm{ha}^{-1}\right.$ season $\left.^{-1}\right)$ : (i) $100 \%$ NPK recommended dosage (P1); (ii) $100 \%$ NPK +80 BioSilAc tablets (P2); (iii) $75 \% \mathrm{NPK}+80$ BioSilAc tablets (P3); (iv) $75 \% \mathrm{NPK}+100$ BioSilAc tablets (P4); (v) $50 \%$ NPK +120 BioSilAc tablets (P5); and (vi) control (P6). The recommended dosage of NPK fertilizers in this location were as follows; $300 \mathrm{~kg}$ Urea $+300 \mathrm{~kg}$ NPK (15-15-15) ha ${ }^{-1}$ season $^{-1}$. Rice var. Cilamaya Muncul was germinated until 21 days. Seedling with 21 days old was planted on the experimental plots with planting distance of $20 \mathrm{x}$ $20 \mathrm{~cm}$ and two seedlings per hole.

BioSilAc (Patent pending) was prepared by using method reported earlier. BioSilAc application was split two times, half at 30 , and half at 45-55 days after planting (DAP). BioSilAc formulated in a tablet form containing $9 \% \mathrm{H}_{4} \mathrm{SiO}_{4}$ enriched with selected $\mathrm{Si}$-solubilizing fungus, i.e. Trichoderma polysporum (Figure 1) (Santi \& Goenadi, 2017; Santi et al., 2017). BioSilAc was applied by spraying into plant and plant root zone after diluting 100 tablets in $500 \mathrm{~L}$ fresh water. Standard crop maintenance was performed including weed, pest, and disease control during the experiment period.

\section{Observation and data analysis}

\section{a. Plant growth and soil chemical analyses}

Plant growth (plant height, number of leaves, and number of tillers) analyses and yield (dried harvested grains) waere observed between P1-P6 treatments at field experiment. Parameter of soil chemical analysis is available $\mathrm{Si}$ using standard methods (Wisconsin State Lab of Hygiene, 1992). This method used ammonium molybdate in acidic conditions can react with silica as well as orthophosphate which produces heteropoly acid. The resulting molybdo-silicate acid was then reduced by ascorbic acid resulting in a complex compound that has a blue-violet absorption that was measured by Spectrophotometer UV-Vis with wavelength of $660 \mathrm{~nm}$ (Wisconsin State Lab of Hygiene, 1992). The observed data of each treatment was analyzed statistically with ANOVA and Duncan's Multiple Range Test (Steel \& Torrie, 1980). 


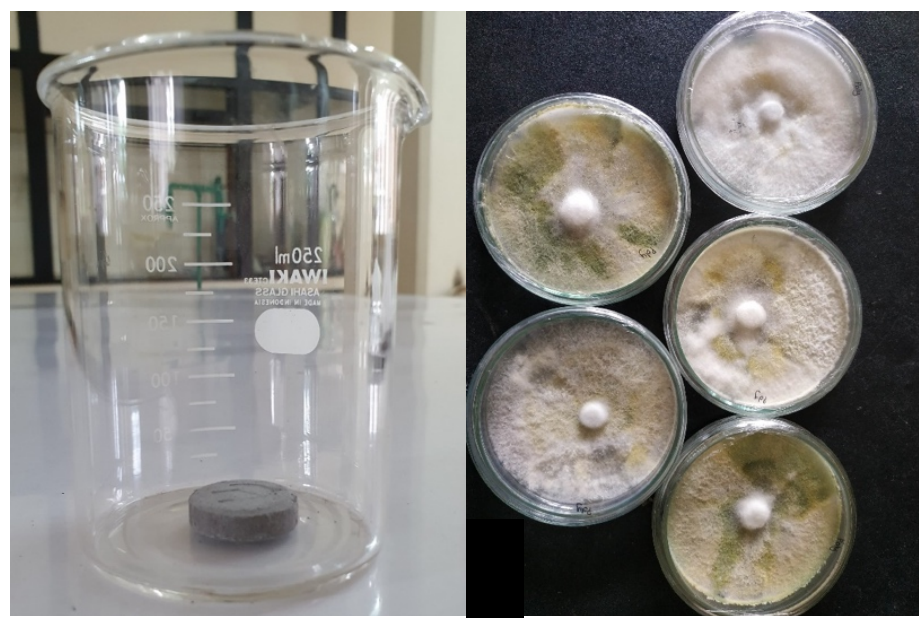

Figure 1. A 4-gram BioSilAc tablet (left) and the growth of Trichoderma polysporum in silicon (Si) -containing medium (right)

Gambar 1. Tablet BioSilAc 4-gram (kiri) dan pertumbuhan Trichoderma polysporum pada media mengandung silikon (Si) (kanan)

\section{b. Total leaves chlorophyll analysis}

Chlorophyll content was determined by the extraction of pigment and pigment content analysis. The measurement of chlorophyll content of the leaves begins with extraction using a $80 \%$ acetone solvent (Wellburn, 1994). The pigment extract in acetone solvent was $80 \%$ measured by UV-VIS spectrophotometers at a wavelength of $663 \mathrm{~nm}$ for chlorophyll a and $646 \mathrm{~nm}$ for chlorophyll b. Concentrations of chlorophyll a and $\mathrm{b}$ as well as total chlorophyll were calculated using the following formula (Wellburn, 1994):

$$
\text { Total chlorophyll }\left(\mathrm{mg} \mathrm{g}^{-1}\right)=\left(17.30 * \mathrm{~A}_{646}\right)+
$$$$
\left(7.18^{*} \mathrm{~A}_{663}\right)
$$

$\mathrm{A}_{663}$ : wavelength chlorophyll a $(663 \mathrm{~nm})$

A646 : wavelength chlorophyll b (646 nm)

\section{c. Scanning Electron Microscopy}

The deposition of Si in leaves and stem in each treatment were observed using the Scanning Electron Microscopy (SEM). Preparation was consisted of 3 stages. First was the fixation stage, the sample soaked in the solution cacodylate buffer (sodium caccodylate trihydrate, $\mathrm{HCl}$ and $\mathrm{H}_{2} \mathrm{O}$ with $\mathrm{pH}$ 7.4). The immersion process was done for \pm 2 hours, then soaked in glutaraldehyde solution $2.5 \%$ for 2 hours and after that in a $2 \%$ tannic acid solution during overnight. Second was the dehydration stage, i.e. the sample soaked sequentially with alcohol $50 \%$ for 4 x 5 minutes, alcohol $70 \%$ for 20 minutes, and alcohol $85 \%$ for 20 minutes at a temperature of $40^{\circ} \mathrm{C}$. Further, the sample was marinated in alcohol $95 \%$ for 20 minutes, an absolute alcohol $2 \times 10$ minutes and TButanol for $2 \times 10$ minutes at room temperature. Third was the gluing stage, i.e. a sample with a size of $1 \times 1 \mathrm{~cm}$ glued to a sterile metal cylinder placed into the ion coating for vacuum, then coated with a metal Pt-Au using an ion coating. The observations with SEM were photographed at a magnification of 350x and 1500x (Talbot \& Rosemary, 2013).

\section{d. Economic analysis for fertilizer application}

Economic analysis for fertilizer application based on calculating the feasibility of fertilizer application. Revenue to cost ratio ( $\mathrm{R} / \mathrm{C}$ ratio) is one indicator of the feasibility of agriculture investment. Treatments with higher yield was evaluated its feasibility by using $\mathrm{R} / \mathrm{C}$ ratio value. If the ratio of $\mathrm{R} / \mathrm{C}>1$ then it means the treatment is considered feasible. The $\mathrm{R} / \mathrm{C}$ ratio was calculated using the following formula (Suratiyah et al., 2003):

$$
\mathrm{R} / \mathrm{C} \text { Ratio }=\frac{\text { Revenue }}{\text { Cost }}
$$

\section{Results and Discussion}

Vegetative growth of rice var. Cilamaya Muncul

The vegetative growth, i.e. plant height, number of leaves and number of tillers at 50 DAP of Rice var. Cilamaya Muncul, was presented in Table 1. The data showed that the application of BioSilAc (P2-P5) tends to improve vegetative growth of the plant compared to P1 (100\% NPK recommendation), and especially to $\mathrm{P} 2$ (100\% $\mathrm{NPK}+80$ BioSilAc tablets) but it was not significant. Plant height was slightly increased by the application of BioSilAc and there was no significant difference among treatments, except P6. This phenomenon was different with number of leaves and number of tillers, by which NPK treatments and the additions of BioSilAc tend to increased them significantly and there were differences among treatments. Our findings were similar to that reported by Gerami et al .(2012) and Pati et al. (2016). In general, the application of BioSilAc tends to improved vegetative growth of 
Table 1. Vegetative growth of rice var. Cilamaya Muncul at 50 DAP

Tabel 1. Pertumbuhan vegetatif padi var. Cilamaya Muncul umur 50 HST

\begin{tabular}{lccc}
\hline $\begin{array}{c}\text { Treatments } \\
\text { Perlakuan }\end{array}$ & $\begin{array}{c}\text { Plant height }(\mathrm{cm}) \\
\text { Tinggi tanaman } \\
(\mathrm{cm})\end{array}$ & $\begin{array}{c}\text { Number of leaves } \\
\text { (strand) } \\
\text { Jumlah daun (helai) }\end{array}$ & $\begin{array}{c}\text { Number of tillers (hill) } \\
\text { Jumlah anakan } \\
\text { (rumpun) }\end{array}$ \\
\hline 100\% NPK recommendation dosage (P1) & $\left.117.5 \mathrm{a}^{*}\right)$ & $141.4 \mathrm{a}$ & $29.6 \mathrm{a}$ \\
$100 \% \mathrm{NPK}+80$ BioSilAc tablets ha $^{-1}(\mathrm{P} 2)$ & $118.2 \mathrm{a}$ & $154.4 \mathrm{a}$ & $30.4 \mathrm{a}$ \\
$75 \% \mathrm{NPK}+80$ BioSilAc tablets ha ${ }^{-1}(\mathrm{P} 3)$ & $113.7 \mathrm{a}$ & $106.0 \mathrm{~b}$ & $20.2 \mathrm{~b}$ \\
$75 \% \mathrm{NPK}+100$ BioSilAc tablets ha ${ }^{-1}(\mathrm{P} 4)$ & $118.7 \mathrm{a}$ & $116.4 \mathrm{~b}$ & $22.4 \mathrm{~b}$ \\
$50 \% \mathrm{NPK}+120$ BioSilAc tablets ha ${ }^{-1}(\mathrm{P} 5)$ & $116.5 \mathrm{a}$ & $108.6 \mathrm{~b}$ & $16.0 \mathrm{c}$ \\
$\mathrm{Control}(\mathrm{P} 6)$ & $102.0 \mathrm{~b}$ & $67.6 \mathrm{c}$ & $11.8 \mathrm{~d}$ \\
\hline CV $(\%)$ & 6.1 & 9.0 & 9.7 \\
\hline *) Means in the same column followed by the same letter are not significantly different according to Duncan's multiple range test at \\
$\alpha=0.05$. \\
*) Angka dalam kolom yang sama diikuti oleh huruf yang sama berarti tidak berbeda nyata menurut uji jarak berganda Duncan \\
pada $\alpha=0,05$.
\end{tabular}

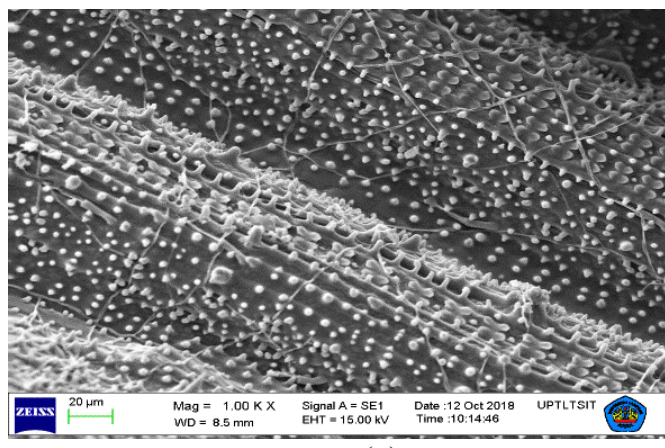

(a)

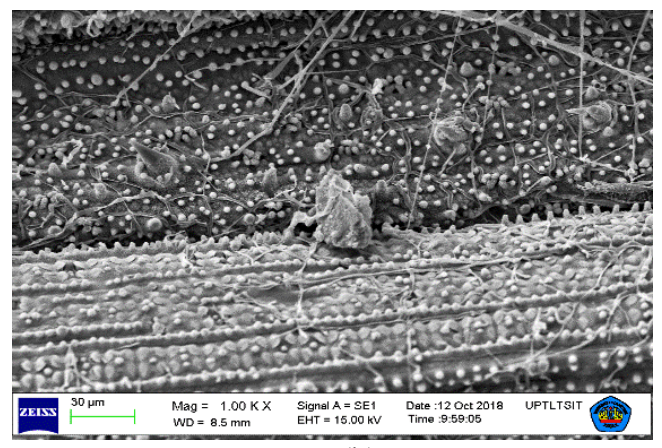

(b)

Figure 2. Scanning Electron Microscopy showing deposition of Si on leaves of without BioSilAc-treated plants (a) and leaves of BioSilAc-treated plants (b)

Gambar 2. Scanning Elektron Mikroskopis yang menunjukkan deposisi Si pada daun tanaman yang tanpa BioSilAc (a) dan daun tanaman yang diberi BioSilAc (b).

rice var. Cilamaya Muncul because the deposition of $\mathrm{Si}$ in cell walls (Figure $2 \mathrm{a}-\mathrm{b}$ ) could increase rice plant height, resulting in a decrease of mutual shading caused by the high density of plant, thereby increasing the photosynthetic rate of the plant due to better light interception (Pati et al., 2016).

\section{Plant physiological of rice var. Cilamaya Muncul}

The soil analysis after harvest (Table 2) indicated that available $\mathrm{Si}$ increased $0.7-6.7 \%$ compared to $\mathrm{P} 1$, and the highest content achieved by P2 treatment (144 ppm). In P6 treatment a significant increased in available $\mathrm{Si}$ content compared to P1 treatment was interesting but the data obtained from this study were not enough to explain this evidence. In the soil solution, $\mathrm{Si}$ is present as mono-silicic acid and poly-silicic acid (Rao et al., 2017). Mono-silic acid and poly-silicic acid are referred to plant available silica (PAS) that is taken up by the plant and has a direct influence on crop growth (Rao \& Susmitha, 2017). Ma et al. (2001) also reported mono-silicic acid is the predominant form of $\mathrm{Si}$ absorbed by roots via active uptake mechanism, where $\mathrm{Si}$ uptake is performed by lateral roots and not by root hairs.
In this research silica content in leaves (Table 2) was significantly different among treatments after harvest. Plants with treatment of $100 \%$ NPK +80 BioSilAc tablets ha $^{-1}$ had a significantly higher $\mathrm{Si}$ content as compared than those $100 \%$ NPK recommendation. Available form of $\mathrm{Si}$ in soil solution is $\mathrm{H}_{4} \mathrm{SiO}_{4}$ and it follows water into the plant root. Silica is translocated from the roots through the xylem until it is deposited under the cuticle and in intercellular spaces (Heckman, 2013). The absorbed water is lost through transpiration and the Si stays in the plant tissue then Si concentration increases in the plant (Mitani et al., 2005). Observation via SEM analysis showed the evidence of Si on the leaves of plant without BioSilAc treatment (P1) (Figure 2a) and leaves of BioSilAc-treated plants (P2) (Figure 2b as well. These evidences were similar to those reported by Ning et al (2014), the results of SEM analysis showed that application of Si-fertilizer to more pronounced cell silicification in rice leaves, and more silica cells, compared to rice leaves without application of Si-fertilizer. As consequent of this evidence, $\mathrm{Si}$ deposition in leaf and stem tissues has been reported to make the plant more resilience to pest and disease attacks (Rao et al., 2017; Alhousari \& Greger, 2018). The presence of 
$\mathrm{Si}$ in plant tissues has also been considered to be responsible in regulating stomatal openness upon drought stress resulting in reduced transpiration rate and at the end less water consumption (Santi et al., 2018, 2019). Overall, these conducive effects of $\mathrm{Si}$ become the reason why this nutrient could support better growth of the crops.

The data (Figure 3 ) showed that the application of BioSilAc tend to improve chlorophyll in leaves among treatments, compared to P1 treatment. This finding was similar to Silva et al. (2012) and Santi et al. (2018), who also reported the application of silica fertilizer improved chlorophyll contents in leaves. The addition of $\mathrm{Si}$ could protect the photosynthetic pigments in leaves, alleviate the damage to chloroplast ultrastructure, and increase the expression genes associated with photosynthesis (Song et al., 2014). Improvement of chlorophyll content will in turn promote efficient metabolism resulting in improved yield as well. The P6 treatment resulted in a higher chlorophyll content in leaves compared to that of P1 treatment. However, the reason for this evidence has been unclear yet, and therefore needs further studies.

\section{Rice yield and fertilizer use efficiency}

Data of rice var. Cilamaya Muncul yield (dried harvested) from each treatment were presented in Figure 4. Application of BioSilAc tend to increased the rice yield compared to $\mathrm{P} 1$, especially $\mathrm{P} 2$. The values range from $1.5(\mathrm{P} 6)$ to $7.1(\mathrm{P} 2)$ ton $\mathrm{ha}^{-1}$ which is in the range of genetic potential yield of 6.0 to 7.0 ton ha $^{-1}$ (BPTP Kalsel, 2011). The highest yield was obtained from combined application of $100 \% \mathrm{NPK}+80$ BioSilAc tablets ha ${ }^{1}$ (P2), i.e. 7.1 ton $\mathrm{ha}^{-1}$. The results showed that the application of P2 increased the rice yield in the form of dried harvested grain by $7.6 \%$ or equivalent to $500 \mathrm{~kg} \mathrm{ha}^{-1}$ compared to the conventional fertilizers recommended dosage (P1).

Table 2. Silica content in soil and leaves after harvest

Tabel 2. Kandungan silika pada tanah dan daun setelah panen

\begin{tabular}{ccc}
\hline $\begin{array}{c}\text { Treatment } \\
\text { Perlakuan }\end{array}$ & $\begin{array}{c}\text { Silica content in soil (ppm) } \\
\text { Kandungan silika pada tanah (ppm) }\end{array}$ & $\begin{array}{c}\text { Silica content in leaves (ppm) } \\
\text { Kandungan silika pada daun (ppm) }\end{array}$ \\
\hline 100\% NPK recommendation dosage $(\mathrm{P} 1)$ & $135 \mathrm{bc}$ & $319 \mathrm{c}$ \\
100\% NPK + 80 BioSilAc tablets ha ${ }^{-1}(\mathrm{P} 2)$ & $144 \mathrm{a}$ & $439 \mathrm{a}$ \\
$75 \% \mathrm{NPK}+80$ BioSilAc tablets ha $^{-1}(\mathrm{P} 3)$ & $138 \mathrm{bc}$ & $377 \mathrm{~b}$ \\
$75 \% \mathrm{NPK}+100$ BioSilAc tablets ha $^{-1}(\mathrm{P} 4)$ & $141 \mathrm{ab}$ & $392 \mathrm{~b}$ \\
$50 \% \mathrm{NPK}+120$ BioSilAc tablets ha $^{-1}(\mathrm{P} 5)$ & $136 \mathrm{bc}$ & $266 \mathrm{~d}$ \\
Control (P6) & $131 \mathrm{~d}$ & $231 \mathrm{~d}$ \\
\hline $\mathrm{CV}(\%)$ & 1.4 & 4.2
\end{tabular}

*) Means in the column followed by the same letter(s) are not significantly different according to Duncan's multiple range test at $\alpha=0.05$.

*) Angka dalam kolom yang sama diikuti oleh huruf yang sama berarti tidak berbeda nyata menurut uji jarak berganda Duncan pada $\alpha$ $=0,05$.

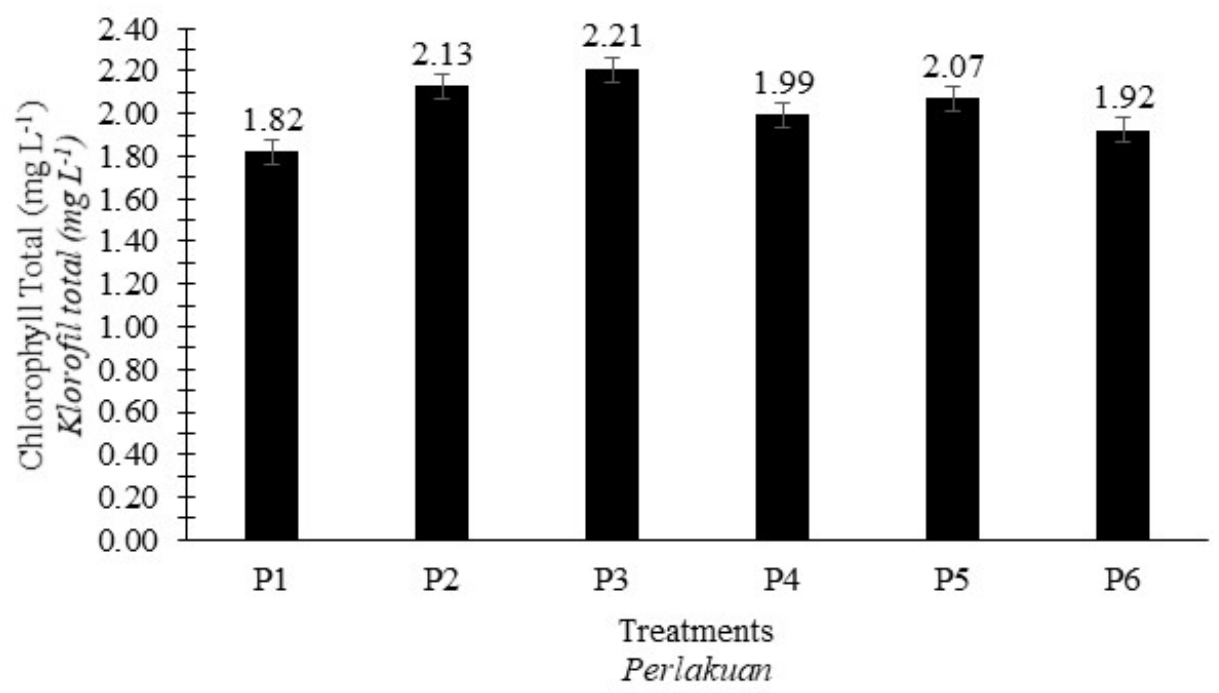

Figure 3. Total leaves chlorophyll of rice var. Cilamaya Muncul under combination treatments of NPK and BioSilAc fertilization after harvest. Treatments $\left(\mathrm{ha}^{-1}\right.$ season $\left.^{-1}\right): 100 \%$ NPK recommended dosage (P1); $100 \% \mathrm{NPK}+80$ BioSilAc tablets (P2); 75\% NPK + 80 BioSilAc tablets (P3); 75\% NPK + 100 BioSilAc tablets (P4); 50\% NPK +120 BioSilAc tablets (P5); and control (P6)

Gambar 3. Klorofil total daun padi var. Cilamaya Muncul dengan kombinasi perlakuan pemupukan NPK dan BioSilAc. Perlakuan : 100\% NPK dosis rekomendasi (ha m $^{-1}$ mism $\left.^{-1}\right)$ (P1); 100\% NPK +80 tablet BioSilAc (P2); 75\% NPK +80 tablet BioSilAc (P3); 75\% NPK +100 tablet BioSilAc (P4); 50\% NPK +120 tablet BioSilAc (P5); dan kontrol (P6) 


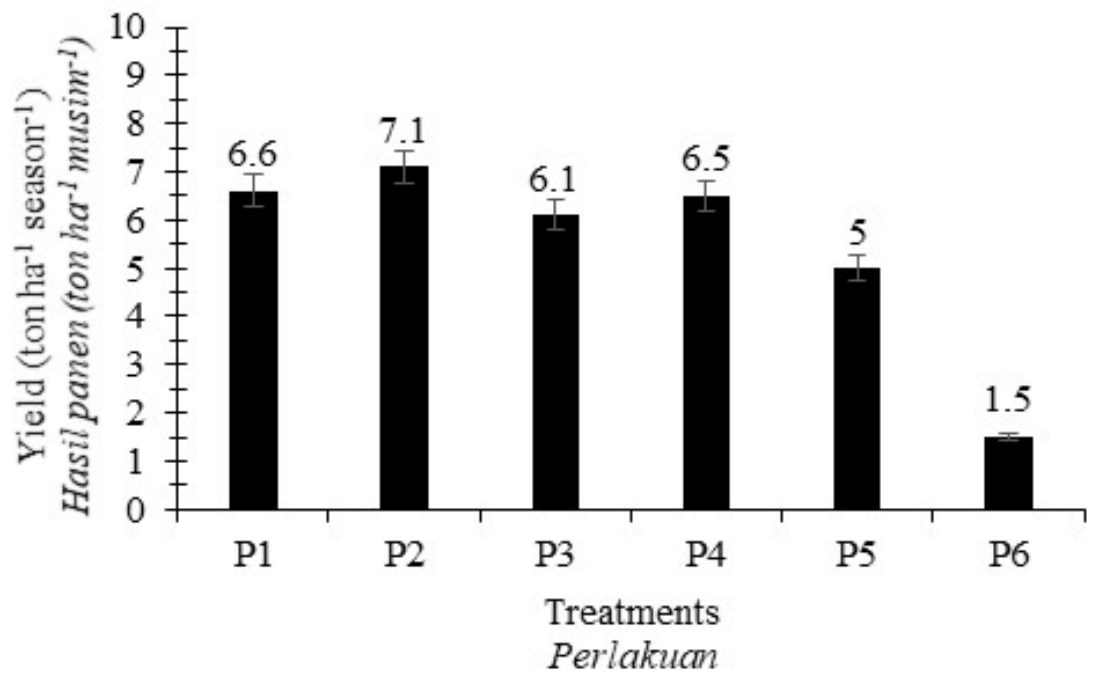

Figure 4. Yield of rice var. Cilamaya Muncul under combination treatments of NPK and BioSilAc fertilization. Treatments: 100\% NPK recommended dosage $\left(\right.$ ha $^{-1}$ season $\left.^{-1}\right)(\mathrm{P} 1) ; 100 \%$ NPK +80 BioSilAc tablets (P2); $75 \%$ NPK +80 BioSilAc tablets (P3); 75\% NPK + 100 BioSilAc tablets (P4); 50\% NPK + 120 BioSilAc tablets (P5); and control (P6)

Gambar 4. Hasil panen padi var. Cilamaya Muncul dengan kombinasi perlakuan pemupukan NPK dan BioSilAc setelah panen. Perlakuan : 100\% NPK dosis rekomendasi $\left(\right.$ ha $^{-1}$ musim $\left.^{-1}\right)(P 1) ; 100 \%$ NPK +80 tablet BioSilAc (P2); $75 \%$ NPK +80 tablet BioSilAc (P3); 75\% NPK + 100 tablet BioSilAc (P4); 50\% NPK + 120 tablet BioSilAc (P5); dan kontrol (P6)

Fertilization efficiency can be achieved by reducing the fertilizer dosage to $75 \%$ NPK +100 BioSilAc tablets ha ${ }^{-1}(\mathrm{P} 4)$ as indicated by the yield obtained at the P4 treatment in which it was not significantly different to that of the conventional fertilizers recommended dosage (P1), i.e. 6.5 tons $\mathrm{ha}^{-1}(\mathrm{P} 4)$ and 6.6 tons $\mathrm{ha}^{-1}(\mathrm{P} 1)$. The results also showed that the addition of BioSilAc was able to save chemical fertilizer up to $25 \%$. In this research, a positive response of grain yield to application of Si fertilizer was observed as also reported earlier by Pati et al. (2016) showing a significant increase in grain yield of rice with increasing Si level. The increase of grain yield might be because the positive effect of Si to increase growth and yield characteristics (Prakash et al., 2011; Pati et al., 2016), enhance photosynthetic activity (Detmann et al., 2012), reduce abiotic and biotic stresses, improve structural support and biomass (Meharg \& Meharg, 2015), and improve nutrient uptake (Pati et al., 2016; Crooks \& Prentice, 2017). Positive response of plant to Si application to some extent could also be attributed to the very low Si content in soil (i.e. $21 \mathrm{ppm}$ ), which was far below the sufficiency level of soluble Si in soils (i.e. 157 ppm) as guided in Japan and South Korea (J. H. Kim, personal communication, 2019).

\section{Economic analysis for fertilizer application}

Economic analysis of rice var. Cilamaya Muncul grown under different treatments, i.e. P1, $\mathrm{P} 2$, and P4 (Table 3), yields different $\mathrm{R} / \mathrm{C}$ (revenue/cost) values as follow: 2.08 (P1), 2.19 (P2), and 2.14 (P4). These values showed that P2 treatment could result in economically feasible fertilization practices. The $\mathrm{R} / \mathrm{C}$ values of treatments P2 was attributed to the addition BioSilAc as supplementary fertilizer (without reduced NPK fertilizer dosage). BioSilAc as supplementary fertilizer can increase profit IDR 2.650.000 per ha. However, further study is needed to confirm these findings especially under different locations and wider area. 
Table 3. Economic analysis of rice var. Cilamaya Muncul yield under combination treatments of NPK and BioSilAc fertilization

Tabel 3. Analisis ekonomi produksi padi var. Cilamaya Muncul dengan kombinasi perlakuan pemupukan NPK dan BioSilAc

\begin{tabular}{|c|c|c|c|c|c|c|}
\hline $\begin{array}{c}\text { Description } \\
\text { Deskripsi }\end{array}$ & $\begin{array}{c}\text { Unit } \\
\text { Satuan }\end{array}$ & $\begin{array}{l}\text { Amount } \\
\text { Jumlah }\end{array}$ & $\begin{array}{l}\text { Price (IDR) } \\
\text { Harga (Rp) }\end{array}$ & $\begin{array}{l}\text { P1 } \\
P 1\end{array}$ & $\begin{array}{l}\mathrm{P} 2 \\
P 2\end{array}$ & $\begin{array}{l}\mathrm{P} 4 \\
P 4\end{array}$ \\
\hline $\begin{array}{l}\text { A. Land Compensation } \\
\text { B. Labor Costs }\end{array}$ & ha & 1 & $2,500,000$ & $2,500,000$ & $2,500,000$ & $2,500,000$ \\
\hline 1. Soil Tillage & $\mathrm{m}^{2}$ & 10,000 & 650 & $6,500,000$ & $6,500,000$ & $6,500,000$ \\
\hline $\begin{array}{l}\text { 2. Planting } \\
\text { 3. Crop maintenances }\end{array}$ & Workday & 15 & 55,000 & 825,000 & 825,000 & 825,000 \\
\hline a. Spraying & Workday & 6 & 55,000 & 330,000 & 330,000 & 330,000 \\
\hline b. Fertilization & Workday & 5 & 55,000 & 275,000 & 385,000 & 385,000 \\
\hline c. Weeding & Workday & 10 & 55,000 & 550,000 & 550,000 & 550,000 \\
\hline $\begin{array}{l}\text { 4. Harvesting } \\
\text { C. Material and Tools }\end{array}$ & Workday & 10 & 55,000 & 550,000 & 550,000 & 550,000 \\
\hline $\begin{array}{l}\text { 1.Paddy seeds } \\
\text { 2.Fertilizers }\end{array}$ & $\mathrm{kg}$ & 20 & 15,000 & 300,000 & 300,000 & 300,000 \\
\hline a. Urea & $50 \mathrm{~kg}$ & 6 & 295,000 & $1,770,000$ & $1,770,000$ & $1,327,500$ \\
\hline b. NPK 15-15-15 & $50 \mathrm{~kg}$ & 6 & 500,000 & $3,000,000$ & $3,000,000$ & $2,250,000$ \\
\hline c. BioSilAc & Tablet & 80 & 3,000 & - & 240,000 & 300,000 \\
\hline 3.Pesticides & ha & 1 & 250,000 & 250,000 & 250,000 & 250,000 \\
\hline Total Cost & & & & $16,850,000$ & $17,200,000$ & $16,067,500$ \\
\hline Production & $\mathrm{Kg} \mathrm{ha}^{-1}$ & & & 6,600 & 7,100 & 6,500 \\
\hline Cost of goods & IDR kg ${ }^{-1}$ & & & 2,553 & 2,423 & 2,472 \\
\hline Income & IDR & & & $34,980,000$ & $37,630,000$ & $34,450,000$ \\
\hline $\mathrm{R} / \mathrm{C}$ ratio & & & & 2.08 & 2.19 & 2.14 \\
\hline
\end{tabular}

*) $100 \%$ NPK recommended dosage (P1); $100 \%$ NPK + 80 BioSilAc tablets (P2); 75\% NPK + 80 BioSilAc tablets (P3); 75\% NPK + 100 BioSilAc tablets (P4); 50\% NPK + 120 BioSilAc tablets (P5); and control (P6); 100\% NPK recommended dosage : $300 \mathrm{~kg}$ Urea $+300 \mathrm{~kg}$ NPK $(15-15-15)$ ha $^{-1}$ season $^{-1}$

*) $100 \%$ NPK dosis rekomendasi (P1); $100 \%$ NPK +80 tablet BioSilAc (P2); $75 \%$ NPK +80 tablet BioSilAc (P3); $75 \%$ NPK +100 tablet BioSilAc (P4); 50\% NPK + 120 tablet BioSilAc (P5); dan kontrol (P6); 100\% dosis rekomendasi NPK : $300 \mathrm{~kg}$ Urea +300 kg NPK (15-15-15) ha ${ }^{-1}$ musim $^{-1}$

\section{Conclusion}

The application of Si fertilizer in the form of BioSilAc on tidal swamp land soil promoted better growth and yield of rice var. Cilamaya Muncul. The highest yield was obtained by combining BioSilAc (80 tablets ha ${ }^{-1}$ season $^{-1}$ ) and NPK recommended dosage. However, at a 100 tablets ha $^{-1}$ season $^{-1}$ dosage, BioSilAc was able to save NPK fertilizer dosages by $25 \%$. Further study is needed to confirm these results, especially under different locations and a wider application.

\section{Acknowledgements}

We would like to extend our sincere gratitude to Development Program of Industry Technology (PPTI), for valuable supports in funding this research (Contract number: 51/G2/PPK/E/E4/ 2019, 11 June 2019) and our farmer colleagues at Sidodadi Village, Ketapang Subdistrict for their kind co-operation in field implementation project and Assessment Institute of Agricultural
Technology, South Lampung, Lampung for their collaboration in this research.

\section{Reference}

Ahmad A, Afzal M, Ahmad AUH \& Tamir M (2013). Effect of foliar application of silicon on yield and quality of rice (Oryza sativa L.). Ceecetari Agron 10 (3), 106-155.

Alhousari F \& M Greger (2018). Silicon and mechanisms of plant resistence to insect pests. Plant 7, 1-11.

Alvarez J \& LE Datnoff (2001). The economic potential of silicon for integrated management and sustainable rice production. CropProtect $20,43-48$.

Amanah DM, N Haris, \& LP Santi (2019). Physiological responses of bio-silica-treated oil palm seedlings to drought stress. Menara Perkebunan 87 (1), 20-30. 
Arsyad DM, B Saidi \& Enrizal (2014). Pengembangan inovasi pertanian di lahan rawa pasang surut mendukung kedaulatan pangan. Pengembangan Inovasi Pertanian 7, 169-176.

Balai Pengkajian Teknologi Pertanian Kalimantan Selatan (2011). Deskripsi sederhana varietas padi tahun 1978-2010. Kalimantan selatan, Balai Pengkajian Teknologi Pertanian Kalimantan Selatan. 120p.

Botta A, FA Rodriguess, N Sierras, C Marin, JM Cerda \& R Brossa (2014) Evaluation of Armurox ${ }^{\circledR}$ (complex of peptide water soluble silicon) on mechanical and biotic stresses in graminae. In: Proceeding $6^{\text {th }}$ Internat. Conf. Silicon in Agric. Stockholm, Sweden, 26-30 August 2014 p. 72.

Crooks R \& P Prentice (2017). Extensive investigation into field based responses to a silica fertilizer. Silicon 9(2), 301-304.

Detmann KC, WL Araújo, SCV Martins, LMVP Sanglard, JV Reis, E Detmann, FÁ Rodrigues, A Nunes-Nesi, AR Fernie, \& FM DaMatta (2012). Silicon nutrition increases grain yield, which, in turn, exerts a feed-forward stimulation of photosynthetic rates via enhanced mesophyll conductance and alters primary metabolism in rice. New Phytol 196 (3), 752-762.

Farooq MA \& KJ Dietz (2015). Silicon as versatile player in plant and human biology: Overlooked and poorly understood. Front Plant Sci 6, 1-14.

Fillipi, MC, ACA Souza, ST Pereira, SA Prabhu \& BG Silva (2014). Silicon and biogents in leaf rice blast suppression. In: Proceeding $6^{\text {th }}$ Internat. Conf. Silicon in Agric. Stockholm, Sweden, 26-30 August 2014 p:46.

Gerami M, A Fallah, \& MRK Moghadam (2012). Study of potassium and sodium silicate on the morphological and chlorophyll content on the rice plant in pot experiment (Oryza sativa L.). Int J Agric Crop Sci. 4 (10), 658-661.

Goenadi DH, LP Santi, J Barus, \& A Dariah (2018). Bio-silifikasi sel dan imobilisasi aluminium oleh bio-nano OSA untuk efisiensi penggunaan air dan hara kedelai hitam di lahan kering masam. Laporan Akhir Kegiatan KP4S Tahun 2018. p 69.

Goenadi DH, LP Santi, A Dariah, J Barus, \& DN Kalbuadi. (2019). Improved black soybean performances grown on selected highly weathered soils by using bio-nano-ortho silicic acid. IOP Conf. Series: Earth and Environmental Science 393.

Heckman J (2013). Silicon: a beneficial substance. Better Crops 97(4), 14-16.
Keeping MG \& OL Reynolds (2009). Silicon in agriculture: New insights, new significance and growing application. Ann Appl Biol 155, 153154.

Lestari AP, IA Rumanti, T Sitaresmi, \& I Khairullah (2019). Tidal swamp tolerant rice lines: climate change adaptive varieties. IOP Conf. Series: Earth and Environmental Science 423.

Ma JF \& E Takahashi (2002). Soil, Fertilizer, and Plant Silicon Research in Japan. Amsterdam : Elsevier, 292 pages

Ma JF, RF Ryan, \& D Delhaize (2001). Aluminium tolerance in plants and the complexing role of organic acids. Trends Plant Sci 6(6), 273-278.

Meena VD, ML Dotaniya, V Coumar, S Rajendiran, S Kundu \& AS Rao (2014). A case for silicon fertilization to improve crop yields in tropical soils. Proc Natl Acad Sci Ind, Sect B: Biol Sci 84, 505-518.

Meharg C \& AA Meharg (2015). Silicon, the silver bullet for mitigating biotic and abiotic stress, and improving grain quality in rice. Environ Exp Bot 120, 8-17.

Mitani N, JF Ma, \& $\mathrm{T}$ Iwashita (2005). Identification of the silicon form in xylem sap of rice (Oryza sativa L.). Plant Cell Physiol 46, 279-283.

Ning D, A Song, F Fan, Z Li, \& Y Liang (2014). Effects of slag-based silicon fertilizer on rice growth and brown-spot resistance. PLoS ONE 9(7), 1-9.

Pati S, B Pal, S Badole, GC Hazra \& B Mandal (2016). Effect of silicon fertilization on growth, yield, and nutrient uptake of rice. Commun Soil Sci Plant Anal 47, 284-290.

Prakash NB, N Chandrashekar, C Mahendra, SU Patil, GN Thippeshappa \& HM Laane (2011). Effect of foliar spray of soluble silicon acid on growth and yield parameters of wetland rice in hilly and coastal zone soils of Karnataka, South India. J Plant Nutr 34, 1883-1893.

Rao GB \& P Susmitha (2017). Silicon uptake, transportation and accumulation in rice. Journal of Pharmacognosy and Phytochemistry 6(6), 290-293.

Rao GB, PY Pi \& EK Syriac (2017). Silicon nutrition in rice: A review. Journal of Pharmacognosy and Phytochemistry Vol. 6(6): 390-392.

Sahebi M, MM Hanafi, ASN Akmar, MY Rafii, P Azizi, FF Tengoua, JNM Azwa, \& M Shabanimofrad (2015). Importance of silicon and mechanisms of biosilica formation in plants. Biomed Research International Article ID 396010, 16 pages. 
Santi LP \& DH Goenadi (2017). Solubilization of silicate from quartz mineral by potential silicate solubilizing bacteria. Menara Perkebunan 85 (2), 95-104.

Santi LP, D Mulyanto, \& DH Goenadi (2017). Double acid-base extraction of silicic acid from quartz sand. Journal of Minerals and Materials Characterization and Engineering 5(6), 362373.

Santi LP, DH Goenadi, J Barus, \& A Dariah (2018). Pengaruh bio-nano silika terhadap hasil dan efisiensi penggunaan air kedelai hitam di lahan kering masam. Jurnal Tanah dan Iklim 42 (1), 43-52

Santi LP, DH Goenadi, J Barus, A Dariah, \& DN Kalbuadi (2019). Effects of bio-nano OSA application on fertilizer use and water consumption efficiencies of black soybean grown on rice-field. Jurnal Tanah dan Iklim 43 (2), 105-112

Silva ON, AKS Lobato, FW Ávila, RCL Costa, CFO Neto, BGS Filho, APM Filho, RP Lemos, JM Pinho, MBCL Medeiros, MS Cardoso, \& IP Andrade (2012). Silicon-induced increase in chlorophyll is modulated by the leaf water potential in two water-deficient tomato cultivars. Plant Soil Environ 58 (11), 481-486.

Siregar AF \& WA Yusuf (2020). Ameliorasi berbasis unsur hara silika di lahan rawa. Jurnal Sumberdaya Lahan 14 (1), 37-47.

Song A, P Li, F Fan, Z Li, \& Y Liang (2014). The effect of silicon on photosynthesis and expression of its relevant genes in rice (Oryza sativa L.) under High-Zinc Stress. PLoS ONE 9(11). e113782. doi:10.1371/journal. pone. 0113782 .

Steel RGD \& JH Torrie (1980). Principles and Procedures of Statistics. A Biometrical approach. $2^{\text {nd }}$ ed. New York, McGraw-Hill.

Suratiyah K, Djuwari, Supriyanto, \& L R Waluyati (2003). Studi analisa usaha tani untuk tujuh (7) komoditas di Kabupaten Bantul. Fakultas Pertanian UGM dan BAPPEDA Kabupaten Bantul. Yogyakarta.

Talbot MJ \& GW Rosemary (2013). Methanol fixation of plant tissue for Scanning Electron Microscopy improves preservation of tissue morphology and dimensions. Plant Methods 9 (36), 1-7.

Wellburn AR (1994). The spectral determination of chlorophyll a and chlorophyll b, as well as total carotenoids, using various solvents with spectrophotometers of different resolution. Journal of Plant Physiology 144 (3), 307-313.

Wiryawan B, H Puspitasari, AK Mahi, M Ahmad \& HA Susanto (2001). Profil sumberdaya wilayah pesisir Desa Pematang Pasir, Kecamatan Ketapang, Lampung Selatan. Penerbitan Proyek Pesisir, Coastal Resources Center, University of Rhode Island. Narraganset, Rhode Island. 40 pp.

Wisconsin State Lab of Hygiene (1992). ESS Method 360.2: Silica Dissolved, Automated, Colorimetric. Wisconsin State Lab of Hygiene 3 (2), 209-212. 